Revue bibliographique pour le domaine irano-aryen

\title{
Anthony O'Mahony, Emma Loosley (eds.). Eastern Christianity in the Modern Middle East
}

Florence Jullien

\section{(2) OpenEdition \\ 12 Journals}

Édition électronique

URL : http://journals.openedition.org/abstractairanica/40861

DOI : 10.4000/abstractairanica.40861

ISSN : 1961-960X

\section{Éditeur :}

CNRS (UMR 7528 Mondes iraniens et indiens), Éditions de l'IFRI

\section{Édition imprimée}

Date de publication : 1 décembre 2013

ISSN : 0240-8910

\section{Référence électronique}

Florence Jullien, «Anthony O'Mahony, Emma Loosley (eds.). Eastern Christianity in the Modern Middle East », Abstracta Iranica [En ligne], Volume 32-33 | 2013, document 341, mis en ligne le 01 juillet 2016 , consulté le 26 septembre 2020. URL : http://journals.openedition.org/abstractairanica/40861 ; DOI : https://doi.org/10.4000/abstractairanica.40861

Ce document a été généré automatiquement le 26 septembre 2020.

Tous droits réservés 


\section{Anthony O'Mahony, Emma Loosley (eds.). Eastern Christianity in the Modern Middle East}

Florence Jullien

\section{RÉFÉRENCE}

Anthony O'Mahony, Emma Loosley (eds.). Eastern Christianity in the Modern Middle East.

London, Routledge, 2010, XIII-184 p.

Quatre chapitres sont dévolus aux Églises syriaques catholiques et orthodoxes en Orient, et notamment en monde iranien. Les contributions offrent un panorama sur les vicissitudes historiques des communautés chrétiennes du Moyen-Orient aux époques moderne et contemporaine.

\section{AUTEURS}

FLORENCE JULLIEN

EPHE, Paris 